\title{
PENGARUH MERGER TERHADAP KINERJA KEUANGAN PERUSAHAAN YANG TERDAFTAR DI DAFTAR EFEK SYARI'AH PERIODE TAHUN 2015-2020
}

\author{
Feri Irawan \\ STAI Nahdlatul Wathan Samawa-NTB \\ feri.irawan@stainwsamawa.ac.id
}

\begin{abstract}
Abstrak: Merger dilakukan oleh perusahaan dengan harapan mendatangkan sejumlah keuntungan. Kondisi saling menguntungkan akan terjadi bila kegiatan merger yang dilakukan menciptakan sinergi, sebagai akibat dari sinergi perusahaan diharapkan akan meningkatkan kinerja perusahaan. Penelitian ini bertujuan untuk menganalisis perbedaan kinerja keuangan perusahaan sebelum dan sesudah merger pada perusahaan yang melakukan aktivitas merger dan terdaftar di Daftar Efek Syariah. Kinerja perusahaan diukur dengan menggunakan rasio keuangan: Current Ratio (CR), Debt to Equity Rasio (DER), Net Profit Margin (NPM), Return On Equity (ROE) dan Return On Asset (ROA). Penelitian ini dilakukan dengan metode kuantitatif, dengan mengambil data dari seluruh perusahaan publik yang melakukan merger di Daftar Efek Syariah (DES) dengan rentang waktu antara tahun 2015-2020, Pengambilan sampel dalam penelitian menggunakan metode purposive sampling, dengan data yang diperoleh sebanyak 5 perusahaan yang melakukan merger. Uji parametric yang digunakan adalah Paired Sample T Test untuk menjawab hipotesis. Hasil dari penelitian ini menunjukkan bahwa pada pengujian secara parsial terhadap 5 rasio keuangan, yaitu adanya perbedaan terhadap CR pada dua tahun sebelum dan sesudah merger, sedangkan pada rasio DER, NPM, ROE dan ROA menunjukan tidak ada perubahan yang signifikan di beberapa tahun pengamatan. Jadi proses merger yang dilakukan perusahaan tidak menunjukkan perubahan yang signifikan karena belum tercapainya sinergi pasca merger. Merger sesuai dengan ekonomi islam sebagai upaya untuk tetap mempertahankan eksistensi perusahaan dan mencegah perusahaan dari kebangkrutan. Dalam hal ini merger diperbolehkan karena menjadi penyelamat bagi perusahaan asal tidak keluar dari etika bisnis Islam.
\end{abstract}

Kata Kunci: Marger, Keuangan Perusahaan, Daftar Efek Syari'ah. 


\section{PENDAHULUAN}

Dewasa ini, laju perkembangan dunia usaha memasuki era globalisasi yang ditandai dengan kemajuan pesat diberbagai bidang komunikasi dan teknologi. Hal tersebut berpengaruh terhadap persaingan usaha yang semakin ketat baik itu perusahaan besar ataupun kecil. Kondisi seperti ini tentu saja menuntut para pengusaha untuk mengambil strategi yang tepat agar dapat mempertahankan kelangsungan hidup perusahaan serta dapat bersaing dengan perusahaan lainnya baik dalam kancah domestik maupun internasional. Untuk menghindari adanya persaingan yang tidak sehat dan saling mengalahkan yang akan merugikan perusahaan satu dengan yang lain, banyak perusahaan yang menjalin kerjasama dalam bentuk penggabungan usaha antara dua atau lebih perusahaan baik dengan perusahaan sejenis maupun yang tidak sejenis. Penggabungan usaha dianggap sebagai salah satu strategi yang dapat dilakukan perusahaan agar bisa survive dan berkembang di tengah ketatnya persaingan usaha di era pasar bebas. Penggabungan usaha dapat dilakukan dengan cara merger, akuisisi dan konsolidasi. Merger adalah salah satu bentuk absorbsi/penyerapan satu perusahaan terhadap perusahaan lain. ${ }^{1}$

Dimana hanya akan ada satu perusahaan yang tetap hidup sebagai badan hukum, sementara yang lainnya akan menghentikan aktivitasnya atau bubar. Adapun yang dimaksud dengan akuisisi adalah pengambilalihan perusahaan melalui pembelian saham biasa atau aset perusahaan tersebut. ${ }^{2}$ Dilakukan dengan pembelian seluruh atau sebagian saham sehingga perusahaan (pengakuisisi) memperoleh kendali atas operasi perusahaan yang diakuisisi. Sedangkan konsolidasi merupakan bentuk khusus dari merger dimana dua atau lebih perusahaan bersama-sama meleburkan diri dan membentuk perusahaan yang baru. ${ }^{3}$ Merger dan akuisisi bisa menjadi alat realokasi sumber daya dan untuk menjalankan strategi perusahaan. ${ }^{4}$ Harapannya agar kinerja keuangan perusahaan yang bergabung dapat meningkat. Merger dan Akuisisi telah menjadi topik populer

\footnotetext{
${ }^{1}$ Abdul Moin, Merger, Akuisisi, \& Divestasi, Edisi Kedua, (Ekonisia: Yogyakarta, 2010), hlm. 6

${ }^{2}$ Brealey, Myers dan Marcus, Dasar Dasar Manajemen Keuangan Perusahaan, Edisi Kelima, (Jakarta: Erlangga, 2006), hlm 206

${ }^{3}$ Abdul Moin, Loc.Cit, h. 10.

${ }^{4}$ Ibid., h. 194
} 
dalam beberapa tahun terakhir ini. Pada awalnya perbincangan ini hanya sebatas pada kalangan komunitas pelaku bisnis, namun sekarang masyarakat umum mulai familiar dengan dua terminologi ini.

Di Indonesia misalnya, kita menyaksikan berbagai peristiwa merger dan akuisisi, seperti merger Bank Mandiri, merger Bank Permata, akuisisi Indofood atas Bogasari, dan akuisisi Kalbe Farma atas Dankos Lab. Dalam skala internasional merger dan akuisisi sudah menjadi hal yang lazim, puluhan bahkan ratusan merger dan akuisisi terjadi setiap harinya. Seperti merger antara Daimler-Benz dengan Crysler, Exxon dengan Mobil Oil, Pharmacia dengan Upjohn, akuisisi Singapore Technologies Telemedia (STT) atas Indosat, dan akuisisi Sony atas Columbia Picture adalah hanya sebagian kecil merger dan akuisisi lintas Negara. ${ }^{5}$ Banyak perusahaan melakukan penggabungan usaha dengan jalan merger. Alasannya adalah karena ada "manfaat lebih" yang akan diperoleh atau perusahaan akan mampu mencapai pertumbuhan lebih cepat dari pada harus membangun unit usaha sendiri. Salah satu motif yang melatarbelakangi suatu perusahaan melakukan merger yaitu motif ekonomi, berkaitan dengan tujuan perusahaan yaitu untuk meningkatkan nilai perusahaan atau memaksimumkan kemakmuran pemegang saham.

Informasi pengumuman merger adalah informasi yang sangat penting dalam suatu industri, karena dua atau lebih perusahaan akan menyatukan kekuatannya. Perubahan-perubahan yang terjadi pada perusahaan setelah melakukan merger akan tampak pada kinerja perusahaan dan penampilan finansialnya. Setelah terjadinya merger kondisi dan posisi keuangan perusahaan mengalami perubahan dan hal ini tercermin dalam laporan keuangan perusahaan yang melakukan merger. Untuk menilai bagaimana keberhasilan merger yang dilakukan, dapat dilihat dari kinerja perusahaan pasca dilakukannya merger, yaitu apakah kinerja keuangannya akan meningkat atau turun serta mungkin stabil atau konstan. Dasar logika dari pengukuran berdasar akuntansi adalah bahwa jika skala betambah besar ditambah dengan sinergi yang dihasilkan dari gabungan aktivitas-aktivitas yang simultan,

\footnotetext{
${ }^{5}$ Abdul Moin, Op.Cit., h. 2
} 
maka laba perusahaan juga semakin meningkat sehingga kinerja perusahaan pasca merger seharusnya semakin baik dibandingkan dengan sebelum merger. ${ }^{6}$

Berdasarkan Keputusan Dewan Komisioner Otoritas Jasa Keuangan Nomor: Kep-22/D.04/2016 tanggal 20 Mei 2016 tentang Daftar Efek Syariah (DES) ada sekitar 321 saham emiten dan perusahaan publik yang masuk dalam Daftar Efek Syariah. ${ }^{7}$ Dari daftar perusahaan yang keluar dan masuk Daftar Efek Syariah, ada sekitar 14 perusahaan yang melakukan merger periode 2005 sampai $2014 .^{8}$

Penggabungan tersebut dilatarbelakangi upaya untuk meningkatkan efisiensi dan produktivitas dalam menghadapi persaingan yang semakin ketat. Langkah tersebut juga dilakukan guna mempertahankan eksistensi perusahaan dan memperkuat pasar. Konsep ajaran Islam mengajarkan tentang kerjasama antara sesama manusia. Hal ini tergambar di dalam QS, Al-Maidah ayat $2:^{9}$

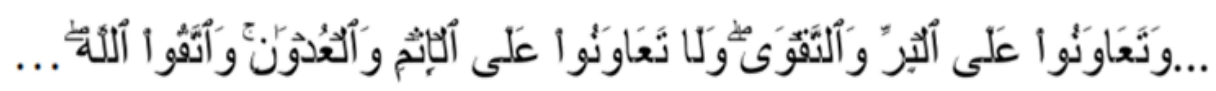

“...dan tolong-menolonglah kamu dalam (mengerjakan) kebajikan dan takwa, dan jangan tolong-menolong dalam berbuat dosa dan pelanggaran. danbertakwalah kamu kepada Allah..."

Berdasarkan ayat diatas, maka jelaslah bahwa kerjasama ini sangat penting bagi kehidupanmanusia, yang dapat menimbulkan rasa setia kawan, sehingga mereka saling membantu dan bertolong menolong mencari rizki yang halal serta mewujudkan kesejahteraan hidup mereka. Sedang tolong menolong dalam kebaikan dan ketaqwaan adalah suatu keharusan yang utama dalam agama islam. Manusia di alam dunia ini tidak mungkin dapat hidup sendiri-sendiri dalam mencukupi keperluannya masing-masing. Sehingga mereka memerlukan kerjasama, terutama dalam bidang pengembangan suatu usaha. Kerjasama

6 annisa meta. cw, "analisis manajemen laba dan kinerja keuangan perusahaan pengakuisisi sebelum dan sesudah merger dan akuisisi yang terdaftar di bursa efek indonesia tahun 2008-2009” diakses 29 februari 2016 pukul 09:21 wib.

7otoritas jasa keuangan, "keputusan dewan komisioner ojk nomor: kep63/d.04/2015 tentang daftar efek syariah" ,http://www.ojk.go.id/id/kanal/syariah/data-danstatistik/daftar-efek-syariah/pages/keputusandkojk-nomor-kep63-d04-2015-tentang-daftarefeksyariah.aspx, diakses 22 maret 2016

8 www.ksei.co.id

9 at-thayyib, al-qur"ean transliterasi perkata dan terjemah perkata, (cipta bagus segara, 2011) h. 106 
merupakan gabungan individualisme dan kepedulian sosial yang terjalin erat, yang bekerja demi kesejahteraan orang lain, sehingga memberikan harapan bagi pengembangan daya guna seseorang. Berdasarkan latar belakang diatas, peneliti ingin mengetahui apakah terdapat perbedaan kinerja keuangan perusahaan antara sebelum dan sesudah merger.

\section{Rumusan Masalah}

Berdasarkan uraian di atas, maka dapat dirumuskan masalah dalam penelitian ini:

1. Bagaimanakah perubahan rasio keuangan perusahaan yang terdaftar pada Daftar Efek Syariah sebelum dan sesudah Merger?

2. Bagaimanakah tinjauan Islam terhadap Merger yang dilakukan perusahaanperusahaan yang terdaftar di Daftar Efek Syariah?

Adapun tujuan penelitian analisis merger terhadap perusahaan adalah sebagai berikut:

a. Untuk menjelaskan pengaruh merger terhadap perubahan rasio keuangan perusahaan yang terdaftar di Daftar Efek Syari'ah (DES) sebelum dan sesudah merger.

b. Untuk mengetahui bagaimana pandangan ekonomi islam terhadap merger yang dilakukan oleh perusahaan-perusahaan sampel.

Manfaat penelitian ini adalah:

a. Secara subyek penelitian ini diharapkan dapat memberikan sumbangsih pemikiran bagi khazanah ilmu ekonomi islam serta dijadikan sebagai sumber informasi bagi investor dalam mengambil keputusan, lebih lanjut penelitian ini diharapkan dapat dijadikan referensi tambahan bagi penelitipeneliti selanjutnya dalam mengamati kinerja perusahaan yang melakukan aktivitas merger.

b. Secara obyek penelitian ini diharapkan sebagai bahan pertimbangan dalam melakukan analisis bagi para pengambil keputusan yang akan melakukan merger. 


\section{LANDASAN TEORI}

A. Merger

Merger berasal dari kata "mergere" (latin) yang artinya (1) bergabung bersama, menyatu, berkombinasi (2) menyebabkan hilangnya identitas karena terserap atau tertelan sesuatu. Merger didefinisikan sebagai penggabungan dua atau lebih usaha yang kemudian hanya ada satu perusahaan yang tetap hidup sebagai badan hukum, sementara yang lainnya menghentikan aktivitasnya atau bubar. ${ }^{10}$

Menurut Hitt, Merger adalah sebuah strategi dimana dua perusahaan setuju untuk menyatukan kegiatan operasionalnya dengan basis yang relatif seimbang, karena mereka memiliki sumber daya dan kapabilitas yang secara bersama-sama dapat menciptakan keunggulan kompetitif yang lebih kuat. ${ }^{11}$ Merger adalah salah satu bentuk absorbsi/penyerapan oleh satu perusahaan terhadap perusahaan lain. Jika perusahaan A dan Perusahaan B melakukan merger, maka hanya akan ada satu perusahaan saja yaitu A atau B. Pada sebagian besar kasus merger, perusahaan yang memiliki ukuran lebih besar akan dipertahankan hidup dan tetap mempertahankan nama dan status hukumnya, sedangkan perusahaan yang ukurannya lebih kecil atau perusahaan yang dimerger akan menghentikan aktivitas atau dibubarkan sebagai badan hukum. Pihak yang masih hidup atau yang menerima merger dinamakan surviving firm atau pihak yang mengeluarkan saham (Issuing Firm). Sementara itu pihak perusahaan yang berhenti dan bubar setelah terjadinya merger dinamakan Merged Firm. ${ }^{12}$

Gambar 1: Ilustrasi Merger

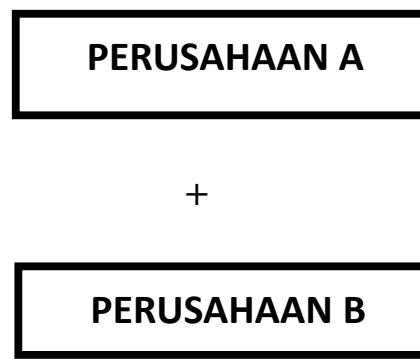

10 Abdul moin, merger akuisisi dan divestas edisi kedua, (yogyakarta: ekonisia, 2010) hlm. 5

11 michael a. Hitt, r. Duane ireland dan robert e. Hoskisson, manajemen strategis: daya saing dan globalisasi; konsep, (jakarta: salemba empat, 2001) hlm. 295.

12 abdul moin, op.cit, hlm. 6 . 
Gambar diatas mengilustrasikan merger antara dua perusahaan yaitu:

Perusahaan A dan perusahaan B. Peristiwa merger mengakibatkan perusahaan A memiliki ukuran yang makin besar, karena ia telah mengambil alih seluruh aset dan hutang Perusahaan B. Pemegang saham atau pemilik perusahaan B akan tetap memiliki saham perusahaan hasil merger melalui pertukaran atau penggantian saham, kecuali jika saham tersebut dijual. Penentuan besarnya nilai pertukaran atau penggantian saham tersebut dilakukan melalui negoisasi kedua belah pihak. Jika saham-saham tersebut diperjualbelikan di pasar modal, maka harga yang disepakati didasarkan pada harga pasar masing-masing saham. Perusahaan memilih merger sebagai strategi adalah karena merger dianggap sebagai jalan cepat untuk mewujudkan tujuan perusahaan dimana perusahaan tidak perlu memulai dari awal bisnis barunya. Adapun menurut ulama fikih, kegiatan merger termasuk kegiatan syirkah atau perkongsian. Syirkah menurut bahasa berarti al-ikhtilath yang artinya campur atau pencampuran. Demikian dinyatakan oleh taqiyuddin. Maksud pencampuran disini ialah seseorang mencampurkan hartanya dengan harta orang lain sehingga tidak mungkin untuk dibedakan. ${ }^{13}$

\section{METODE PENELITIAN}

Jenis penelitian yang penulis lakukan adalah penelitian deskriptif yaitu suatu penelitian yang hanya menggambarkan, melukiskan, memaparkan dan melaporkan suatu keadaan objek penelitian dengan mengkomparasikan antara teori dengan keadaan yang terjadi di lapangan, apakah ada kesenjangan atau mungkin kesamaan antara teori dengan keadaan di lapangan. ${ }^{14}$

Adapun penelitian ini bersifat komparatif atau sifatnya membandingkan. Penelitian ini dilakukan untuk membandingkan persamaan dan perbedaan dua atau lebih fakta-fakta dan sifat-sifat objek yang diteliti berdasarkan kerangka pemikiran tertentu. ${ }^{15}$ Penelitian ini membandingkan kinerja keuangan perusahaan yang terdaftar di Daftar Efek Syariah antara sebelum dan sesudah merger.

\footnotetext{
${ }^{13}$ (H. Hendi Suhendi, Fiqh Muamalah, Rajawali Press, Jakarta, edisi 1 cet ke 8 2013.) h. 125

${ }^{14}$ M. Ahmad Anwar, Prinsip-Prinsip Metodologi Research, (Yogyakarta: Sumbangsih, 1975), h. 33

${ }^{15}$ M. Nazir, Metodologi penelitian, (Bogor: Ghalia Indonesia, 2005), h. 58.
} 
Data adalah sekumpulan bukti atau fakta yang dikumpulkan dan disajikan untuk tujuan tertentu. ${ }^{16}$ Sumber data dalam penelitian adalah subyek asal data dapat diperoleh, sumber data penelitian merupakan faktor penting yang menjadi pertimbangan dalam menentukan metode penulisan data. Data yang digunakan dalam penelitian ini adalah data sekunder. Data sekunder yaitu data yang diperoleh dari kantor, buku (kepustakaan), atau pihak-pihak lain yang memberikan data yang erat kaitannya dengan objek dan tujuan penelitian ${ }^{17}$

Selain itu data yang digunakan adalah data kuantitatif yaitu data yang berupa angka-angka dan analisis menggunakan statistik ${ }^{18}$ Dalam penelitian ini, data yang akan diolah oleh penulis bersumber dari laporan keuangan perusahaan yang terdaftar dalam list Daftar Efek Syariah yang laporan keuangannya dipublikasikan di Bursa Efek Indonesia. Populasi adalah wilayah generalisasi yang terdiri atas: obyek/subyek yang mempunyai kualitas dan karakteristik tertentu yang diterapkan oleh peneliti untuk dipelajari dan kemudian ditarik kesimpulannya. ${ }^{19}$ Pada penelitian ini, populasi berupa semua perusahaan yang melakukan merger dan terdaftar di Daftar Efek Syariah. Berdasarkan Keputusan Dewan Komisioner Otoritas Jasa Keuangan Nomor: Kep-22/D.04/2016 tanggal 20 Mei 2016 tentang Daftar Efek Syariah (DES) ada sekitar 321 saham emiten dan perusahaan publik yang masuk dalam Daftar Efek Syariah. Dari daftar perusahaan yang keluar dan masuk Daftar Efek Syariah, selama periode 2005 sampai 2014 tercatat sekitar 14 perusahaan telah melakukan merger.

\footnotetext{
${ }^{16}$ Moh. Pabundu Tika, Metodologi Risearch Bisnis, (Jakarta: PT. Bumi Aksara, 2006), h. 57

${ }_{17}$ Moh. Pabundu Tika, Op.Cit, hlm. 64

${ }^{18}$ Sugiyono, Metode Penelitian Bisnis, Cetakan ke-16 (Bandung: Alfabeta, 2012), h. 12

19 Sugiono, Metode Penelitian Kuantitatif Kualitatif dan R\&D, Cetakan Ke-17, (Bandung:
} Alfabeta, 2012) h. 80 
Secara spesifik, kinerja keuangan disini difokuskan terhadap kinerja keuangan perusahaan yang melakukan merger. Kinerja keuangan perusahaan diukur dengan rasio keuangan, yaitu meliputi:

\section{Current Ratio (CR)}

Current ratio adalah ukuran yang umum digunakan atas solvensi jangka pendek, kemampuan suatu perusahaan memenuhi kebutuhan hutang ketika jatuh tempo. Current ratio atau rasio lancar dihitung menggunakan cara:

$$
\text { Current Ratio }=\frac{\text { Aset Lancar }}{\text { Hutang Lancar }}
$$

\section{Debt to Equity Ratio (DER)}

Adalah perbandingan antara hutang-hutang dengan ekuitas dalam pendanaan perusahaan dan menunjukkan kemampuan modal sendiri perusahaan untuk memenuhi seluruh kewajibannya. Rasio ini mengukur kemampuan pemilik perusahaan dengan equity yang dimilikinya untuk membayar hutang kepada kreditur. Semakin tinggi rasio ini maka semakin banyak uang kreditur yang digunakan sebagai modal kerja yang diharapkan dapat meningkatkan laba perusahaan. Debt to Equity Ratio dihitung dengan menggunakan cara:

$$
\text { Debt to Equity Ration }=\frac{\text { Total Utang }}{\text { Total Modal Sendiri }}
$$

3. Net Profit Margin (NPM)

Mengukur seberapa banyak laba bersih setelah pajak dan bunga yang dapat dihasilkan dari penjualan atau pendapatan. Dihitung dengan menggunakan rumus:

$$
\text { Net Profit Margin }=\frac{\text { Earning After Tex }(\mathrm{EAT})}{\text { Sales }}
$$

\section{Return On Equity (ROE)}

Mengukur seberapa besar keuntungan bersih yang tersedia bagi pemegang saham. Dihitung dengan menggunakan rumus:

$$
\text { Return On Equity }=\frac{\text { Earning After text }(E A T)}{\text { Shareholders Equity }}
$$

\section{Return On Assets (ROA)}

Mengukur keuntungan yang dihasilkan dari seluruh aktiva yang dimiliki perusahaan. Dihitunng dengan menggunakan rumus: 


$$
\text { Return On Assets }=\frac{\text { Earning After Taxt }(E A T)}{\text { Total Asset }}
$$

\section{HASIL DAN PEMBAHASAN}

\section{A. HASIL ANALISIS DATA}

\section{Statistik Deskriptif}

Menurut Singgih Santoso analisis statistik deskriptif memberikan gambaran atau deskripsi suatu data yang dilihat dari nilai rata-rata (mean), standar deviasi, maksimum, dan minimum. Statistik deskriptif merupakan bagian dari analisis data yang memberikan gambaran awal setiap variabel yang digunakan dalam penelitian. Variabel dependen dalam penelitian ini adalah kinerja perusahaan, sedangkan variabel independennya adalah Merger. Analisis deskriptif menggunakan data asli perusahaan. Adapun deskripsi data rasio keuangan disajikan dalam tabel berikut ini:

Tabel. 1

Hasil Statistik Deskriptif Sebelum Perusahaan Sampel Melakukan Merger

\begin{tabular}{|l|l|l|l|l|l|l|l|}
\hline \multicolumn{1}{|c|}{ Rasio } & \multicolumn{2}{c|}{ Variabel } & N & \multicolumn{1}{c|}{ Min } & Maks & \multicolumn{1}{c|}{ Mean } & $\begin{array}{c}\text { Std. } \\
\text { Deviation }\end{array}$ \\
\hline Likuiditas & CR & Sebelum & 10 & 34,97 & 423,87 & 218,5480 & 128,64989 \\
\hline Solvabilitas & DER & Sebelum & 10 & 0,02 & 9,04 & 1,6540 & 2,748067 \\
\hline Aktivitas & NPM & Sebelum & 10 & $-45,61$ & 64,24 & 6,4000 & 29,01130 \\
\hline \multirow{2}{*}{ Profitabilitas } & ROE & Sebelum & 10 & $-158,40$ & 31,30 & $-6,3010$ & 56,20023 \\
\cline { 2 - 8 } & ROA & Sebelum & 10 & $-15,78$ & 17,58 & 5,4890 & 10,33079 \\
\hline
\end{tabular}

Sumber: data diolah pada tahun 2019

Hasil deskriptif variabel sebelum dengan sesudah perusahaan sampel melakukan merger seperti yang ditampilkan tabel 4, dapat dijelaskan sebagai berikut:

1. Nilai rata-rata CR untuk satu tahun sebelum merger sebesar 218,5480 dengan standar deviasi 128,64989. Nilai standar deviasi yang lebih rendah dari rata rata menunjukan adanya variasi yang rendah antara nilai maksimum dan minimum. Nilai rata-rata CR sebesar 218,5480 menunjukkan bahwa rata-rata kemampuan perusahaan, dengan menggunakan aktiva lancar untuk menutup hutang lancar adalah sebesar 
218,5480 kali. Sedangkan masing-masing nilai maksimum dan minimum adalah 423,87 dan 34,97.

2. Nilai rata-rata DER untuk satu tahun sebelum merger sebesar 1,6540 dengan standar deviasi 2,748067. Nilai standar deviasi yang lebih besar dari nilai rata rata menunjukan adanya variasi yang besar antara nilai maksimum dan minimum. Nilai rata-rata DER sebesar 1,6540 menunjukan bahwa rata-rata tingkat hutang terhadap ekuiti perusahaan adalah sebesar 1,6540 kali. Sedangkan masing-masing nilai maksimum dan minimum adalah 9,04 dan 0,02.

3. Nilai rata-rata NPM untuk satu tahun sebelum merger sebesar 6,4000 dengan standar deviasi 29,01130. Nilai standar deviasi yang lebih besar dari rata rata menunjukan adanya variasi yang besar atau adanya kesenjangan yang cukup besar antara nilai maksimum dan minimum. Nilai rata-rata NPM sebesar 6,4000 menunjukan bahwa rata-rata tingkat pengembalian keuntungan bersih perusahaan adalah sebesar 6,4000 kali. Sedangkan masing-masing nilai maksimum dan minimum adalah 64,24 dan-45,61.

4. Nilai rata-rata ROE untuk satu tahun sebelum merger sebesar $-6,3010$ dengan standar deviasi 56,20023. Nilai standar deviasi yang lebih besar dari rata rata menunjukan adanya variasi yang besar antara nilai maksimum dan minimum. Nilai rata-rata ROE sebesar -6,3010 menunjukan bahwa rata-rata untuk mengukur tingkat pengembalian atas ekuitas saham biasa sebesar -6,3010\%. Sedangkan masing-masing nilai maksimum dan minimum adalah 31,30dan -158,4.

5. Nilai rata-rata ROA untuk satu tahun sebelum merger sebesar 5,4890 dengan standar deviasi 10,33079. Nilai standar deviasi yang lebih besar dari rata rata menunjukan adanya variasi yang besar antara nilai maksimum dan minimum. Nilai rata-rata ROA sebesar 5,4890 menunjukan bahwa rata-rata efektivitas perusahaan didalam menghasilkan keuntungan dengan memanfaatkan aktiva yang dimiliki 
adalah sebesar 5,4890\%. Sedangkan masing-masing nilai maksimum dan minimum adalah 17,58 dan $-15,78$.

Tabel. 2

Hasil Statistik Deskriptif Sesudah Perusahaan Sampel Melakukan Merger

\begin{tabular}{|c|c|c|c|c|c|c|c|}
\hline Rasio & \multicolumn{2}{|c|}{ Variabel } & $\mathbf{N}$ & Min & Maks & Mean & Std. \\
\hline Likuiditas & CR & Sesudah & 10 & 60,17 & 206,46 & 138,6780 & 51,03577 \\
\hline Solvabilitas & DER & Sesudah & 10 & 0,70 & 3,15 & 1,5130 & 0,79270 \\
\hline Aktivitas & NPM & Sesudah & 10 & $-3,82$ & 9,83 & 3,2680 & 3,90163 \\
\hline Profitabilitas & ROE & Sesudah & 10 & $-12,10$ & 16,41 & 5,1040 & 7,97220 \\
\hline & ROA & Sesudah & 10 & $-5,17$ & 6,39 & 1,9670 & 3,26540 \\
\hline
\end{tabular}

Sumber: diolah pada tahun 2016

Hasil deskriptif variabel sebelum dengan sesudah perusahaan sampel melakukan merger seperti yang ditampilkan tabel 5, dapat dijelaskan sebagai berikut:

1. Nilai rata-rata CR untuk satu tahun sebelum merger sebesar 138,6780 dengan standar deviasi 51,03577. Nilai standar deviasi yang lebih rendah dari rata rata menunjukan adanya variasi yang rendah antara nilai maksimum dan minimum. Nilai rata-rata $\mathrm{CR}$ sebesar 138,6780 menunjukkan bahwa rata-rata kemampuan perusahaan, dengan menggunakan aktiva lancar untuk menutup hutang lancar adalah sebesar 138,6780 kali. Sedangkan masing-masing nilai maksimum dan minimum adalah 206,46 dan 60,17 .

2. Nilai rata-rata DER untuk satu tahun sebelum merger sebesar 1,5130 dengan standar deviasi 0,79270. Nilai standar deviasi yang lebih kecil dari nilai rata rata menunjukan adanya variasi yang rendah antara nilai maksimum dan minimum. Nilai rata-rata DER sebesar 1,5130 menunjukan bahwa rata-rata tingkat hutang terhadap ekuiti perusahaan adalah sebesar 1,5130 kali. Sedangkan masing-masing nilai maksimum dan minimum adalah 3,15 dan 0,70 
3. Nilai rata-rata NPM untuk satu tahun sebelum merger sebesar 3,2680 dengan standar deviasi 3,90163. Nilai standar deviasi yang lebih besar dari rata rata menunjukan adanya variasi yang besar atau adanya kesenjangan yang cukup besar antara nilai maksimum dan minimum. Nilai rata-rata NPM sebesar 3,2680 menunjukan bahwa rata-rata tingkat pengembalian keuntungan bersih perusahaan adalah sebesar 3,2680 kali. Sedangkan masing-masing nilai maksimum dan minimum adalah 9,83 dan $-3,82$.

4. Nilai rata-rata ROE untuk satu tahun sebelum merger sebesar 5,1040 dengan standar deviasi 7,97220. Nilai standar deviasi yang lebih besar dari rata rata menunjukan adanya variasi yang besar antara nilai maksimum dan minimum. Nilai rata-rata ROE sebesar 5,1040 menunjukan bahwa rata-rata untuk mengukur tingkat pengembalian atas ekuitas saham biasa sebesar 5,1040\%. Sedangkan masing-masing nilai maksimum dan minimum adalah 16,41 dan $-12,10$

5. Nilai rata-rata ROA untuk satu tahun sebelum merger sebesar 1,9670 dengan standar deviasi 3,26540. Nilai standar deviasi yang lebih besar dari rata rata menunjukan adanya variasi yang besar antara nilai maksimum dan minimum. Nilai rata-rata ROA sebesar 1,9670 menunjukan bahwa rata-rata efektivitas perusahaan didalam menghasilkan keuntungan dengan memanfaatkan aktiva yang dimiliki adalah sebesar $1,9670 \%$. Sedangkan masing-masing nilai maksimum dan minimum adalah 6,39 dan $-5,17$.

\section{Uji Normalitas}

Uji normalitas yang digunakan adalah Kolmogorov-Smirnov Test. Taraf signifikansi yang digunakan adalah $5 \%$ atau 0,05 . Data dinyatakan berdistribusi normal jika signifikansi lebih besar dari 0,05. Sedangkan data dinyatakan tidak berdistribusi normal jika signifikansi kurang dari 0,05. Hasil dari uji normalitas disajikan dalam tabel dibawah ini: 
Tabel. 3

Hasil Uji Normalitas Kolmogorov Smirnov Test

\begin{tabular}{|l|l|l|l|l|}
\hline Periode & Variabel & $\begin{array}{l}\text { Sig. (2- } \\
\text { tailed) }\end{array}$ & $\begin{array}{l}\text { Taraf } \\
\text { Signifikansi }\end{array}$ & Kesimpulan \\
\hline Sebelum & CR & 0,964 & 0,05 & Normal \\
\cline { 2 - 5 } & DER & 0,132 & 0,05 & Normal \\
\cline { 2 - 5 } & NPM & 0,454 & 0,05 & Normal \\
\cline { 2 - 5 } & ROE & 0,160 & 0,05 & Normal \\
\cline { 2 - 5 } & ROA & 0,663 & 0,05 & Normal \\
\hline Sesudah & CR & 0,986 & 0,05 & Normal \\
\cline { 2 - 5 } & DER & 0,878 & 0,05 & Normal \\
\cline { 2 - 5 } & NPM & 0,994 & 0,05 & Normal \\
\cline { 2 - 5 } & ROE & 0,921 & 0,05 & Normal \\
\cline { 2 - 5 } & ROA & 0,850 & 0,05 & Normal \\
\hline
\end{tabular}

Sumber: data diolah pada tahun 2016

Berdasarkan hasil uji normalitas diatas, diketahui bahwa semua data sebelum maupun sesudah merger mempunyai nilai probabilitas $>$ taraf signifikansi $(a=0.05)$ sehingga dapat disimpulkan bahwa data-data rasio keuangan berdistribusi normal.

\section{Pengujian Hipotesis}

hasil penelitian yang meliputi pengujian hipotesis yang terdiri dari lima hipotesis. Pengujian hipotesis dilakukan untuk menjawab pertanyaan apakah kinerja keuangan perusahaan sampel yang diajukan dengan menggunakan lima rasio keuangan setelah merger berbeda dibandingkan dengan kinerja perusahaan sebelum melakukan merger.

Perbandingan tersebut dilakukan untuk mengetahui program keputusan merger terhadap kinerja perusahaan secara finansial. Untuk menganalisis pengaruh merger terhadap perusahaan secara fundamental yaitu pengaruhnya terhadap kondisi keuangan perusahaan. Rasio-rasio tersebut dibandingkan dengan rasiorasio sebelum perusahaan melakukan merger. Jika variabel-variabel yang dibandingkan berbeda, maka dinyatakan bahwa merger berpengaruh terhadap kinerja perusahaan tersebut. Pengujian statistik dalam penelitian ini menggunakan 
uji statistik parametrik yaitu uji paired sample t test karena data yang digunakan berdistribusi normal.

Uji paired sample t test dilakukan untuk mengetahui signifikansi perubahan kinerja keuangan perusahaan publik sebelum dan sesudah melakukan merger dengan membandingkan masing-masing indikator (rasio). Dari uji perbandingan statistik dengan menggunakan paired sample t test ini akan diambil kesimpulan untuk menerima atau menolak hipotesis yang diajukan. Hipotesis diterima apabila nilai signifikansi <taraf signifikansi $(a)=0,05$. Sebaliknya apabila $p>0,05$, maka hipotesis tidak terbukti atau ditolak.

Tabel. 4

Hasil uji paired sample $t$ test sebelum dengan sesudah merger

\begin{tabular}{|l|l|l|l|l|l|}
\hline Hipotesis & Variabel & t-hitung & $\begin{array}{c}\text { Sig. } \\
(\mathbf{2}-\text { tailed })\end{array}$ & $\boldsymbol{\alpha}$ & Kesimpulan \\
\hline $\mathrm{H}_{1}$ & $\mathrm{CR}$ & 2,225 & $0,053^{*}$ & 0,1 & Diterima \\
\hline $\mathrm{H}_{2}$ & DER & 0,214 & 0,835 & 0,05 & Ditolak \\
\hline $\mathrm{H}_{3}$ & NPM & 0,345 & 0,738 & 0,05 & Ditolak \\
\hline $\mathrm{H}_{4}$ & ROE & $-0,622$ & 0,549 & 0,05 & Ditolak \\
\hline $\mathrm{H}_{5}$ & ROA & 0,982 & 0,352 & 0,05 & Ditolak \\
\hline
\end{tabular}

Data diolah pada tahun 2016

Keterangan: $*=\operatorname{sig}(a=0,10)$

Berdasarkan tabel 7 diatas, menunjukkan bahwa:

1. Hasil analisis data pada variabel $\mathrm{CR}$, diperoleh t-hitung sebesar 2,225 dengan signifikansi 0,053 yang nilai signifikansi lebih kecil dari 0,1 $(0.053<0.1)$ dengan demikian terdapat perbedaan pada variabel $\mathrm{CR}$ dengan masa perbandingan 2 tahun sebelum dengan dua tahun setelah.

2. Hasil analisis data pada variabel DER, diperoleh t-hitung sebesar 0,214 dengan signifikansi 0,835. Karena nilai signifikansi lebih besar dari 0,05 $(0,835>0,05)$ maka berarti tidak terdapat perbedaan pada variabel DER dengan masa perbandingan 2 tahun sebelum dengan dua tahun setelah.

3. Hasil analisis data pada variabel NPM, diperoleh t-hitung sebesar 0,345 dengan signifikansi 0,738. Karena nilai signifikansi lebih besar dari 0,05 
$(0,738>0,05)$ maka berarti tidak terdapat perbedaan pada variabel NPM dengan masa perbandingan 2 tahun sebelum dengan dua tahun setelah.

4. Hasil analisis data pada variabel ROE, diperoleh t-hitung sebesar -0,622 dengan signifikansi 0,549. Karena nilai signifikansi lebih besar dari 0,05 $(0,549>0,05)$ maka berarti tidak terdapat perbedaan pada variabel ROE dengan masa perbandingan 2 tahun sebelum dengan dua tahun setelah.

5. Hasil analisis data pada variabel ROA, diperoleh t-hitung sebesar 0,982 dengan signifikansi 0,352. Karena nilai signifikansi lebih besar dari 0,05 $(0,352>0,05)$ maka berarti tidak terdapat perbedaan pada variabel ROA dengan masa perbandingan 2 tahun sebelum dengan dua tahun setelah.

\section{B. PEMBAHASAN}

1. Kinerja Keuangan Perusahaan Sebelum dan Sesudah Merger

Dengan menggunakan uji paired sample t test dengan tingkat signifikansi 5\% menunjukkan bahwa perubahan yang terjadi antara sebelum dan sesudah melakukan merger adalah tidak nyata. Namun apabila taraf nyata dinaikkan menjadi $10 \%$ maka perubahan signifikan terjadi pada rasio likuiditas, hal ini menandakan bahwa current ratio mengalami perbedaan setelah dilakukan merger (pada variabel ini nilai signifikansi $=0,053$ ). Hasil analisis data terhadap variabel CR diperoleh nilai t sebesar 2,225 dengan signifikansi sebesar 0,053, karena nilai signifikansi lebih kecil dari $0,1(0,053<0,1)$ maka $\mathrm{H}_{1}$ diterima. Artinya terdapat perbedaan CR pada periode 2 tahun sebelum dengan 2 tahun setelah merger. Hasil penelitian ini sejalan dengan penelitian Hamidah dan Manasye Noviani, terdapat perbedaan pada periode dua tahun sebelum dengan dua tahun sesudah merger, yang berarti efisiensi perusahaan dalam menggunakan aktiva lancarnya untuk mengelola kewajiban lancar semakin meningkat setelah penggabungan badan usaha.

Hasil analisis terhadap debt to equity ratio menunjukkan bahwa tidak terdapat perbedaan yang signifikan pada kinerja keuangan pasca merger. Hal ini menunjukkan bahwa $\mathrm{H}_{2}$ tidak dapat diterima. Hasil ini sesuai dengan penelitian Indah Rahmawati yang menduga lemahnya strategi yang dilakukan dalam pemilihan perusahaan target. Hasil analisis terhadap rasio profitabilitas menunjukkan bahwa merger tidak berpengaruh signifikan terhadap profitabilitas 
perusahaan, baik itu terhadap net profit margin, return on equity maupun return on assets. Hasil ini konsisten dengan hasil penelitian Annisa Meta dan Muhammad Aji Nugroho yang menyatakan NPM, ROE, dan ROA tidak berbeda pasca merger, hasil ini menunjukan bahwa keinginan ekonomis yang ingin memperbaiki profitabilitas pasca merger menjadi tidak terwujud.

Hal ini kemungkinan disebabkan alasan non-ekonomi seperti menyelamatkan perusahaan dari ancaman kebangkrutan dana alasan yang sifatnya pribadi yang mungkin lebih banyak dipertimbangkan. Sehingga $\mathrm{H}$ beda pada penelitian ini, $\mathrm{H}_{2}$, $\mathrm{H}_{3}, \mathrm{H}_{4}$, dan $\mathrm{H}_{5}$ ditolak berdasarkan uji beda pada penelitian ini. Peningkatan dan penurunan yang terjadi pada rasio-rasio keuangan tidak cukup kuat untuk menunjukkan adanya pengaruh merger terhadap kinerja keuangan yang diajukan sebagai hipotesis. Hal ini dibuktikan dengan tidak adanya perbedaan yang signifikan kelima rasio kecuali current ratio yang memiliki perbedaan antara dua tahun sebelum dan dua tahun sesudah merger. Sehingga hasil penelitian ini memberikan indikasi bahwa memang tujuan ekonomis yang diharapkan terjadi setelah merger belum tercapai. Jadi, kinerja perusahaan setelah melakukan merger ternyata tidak mengalami perbaikan dibandingkan dengan sebelum melaksanakan merger. Hasil pengujian ini dapat dimungkinkan untuk terjadi dikarenakan periode pengamatan dalam penelitian ini hanya lima tahun (dua tahun sebelum dan dua tahun sesudah merger).

\section{Merger dalam Perspektif Ekonomi Islam}

Didalam Islam bukanlah suatu larangan, apabila manusia mempunyai rencana atau keinginan untuk berhasil dalam usahanya. Namun dengan syarat rencana itu tidak bertentangan dengan ajaran (syariat) Islam. Allah berfirman: ${ }^{20}$

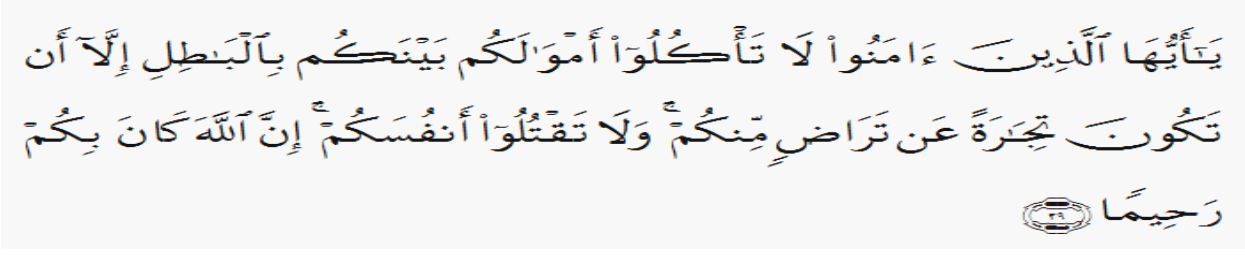

"Hai orang-orang yang beriman, janganlah kamu saling memakan harta sesamamu dengan jalan yang batil, kecuali dengan jalan perniagaan yang

${ }^{20}$ QS An-nisa (4) : 29 
berlaku dengan suka sama-suka di antara kamu. Dan janganlah kamu membunuh dirimu; sesungguhnya Allah adalah Maha Penyayang kepadamu"

Secara umum hukum ekonomi syariah tidak menghalangi atau mengharamkan pelaksanaan merger. Akan tetapi, pelaksanaan merger itu tidak boleh keluar dari etika bisnis syariah dan hukum kontrak syariah. Bisnis dalam Islam memposisikan pengertian bisnis yang pada hakikatnya merupakan usaha manusia untuk mencari keridhaan Allah SWT, tidak boleh dilakukan dengan cara penipuan dan kebohongan hanya demi memperoleh keuntungan dan berorientasi kepada sikap ta'awun. Kejujuran merupakan syarat paling mendasar dalam kegiatan bisnis, Rasulullah sangat intens menganjurkan kejujuran dalam aktivitas bisnis. Dalam hal ini, beliau bersabda:

"Tidak dibenarkan seorang muslim menjual satu jualan yang mempunyai aib, kecuali ia menjelaskan aibnya" (HR. Al-Quzwani).

Pelaku bisnis menurut Islam, tidak hanya sekedar mengejar keuntungan sebanyak-banyaknya tetapi juga berorientasi kepada sikap ta'awun (tolong menolong) sebagai aspek sosial kegiatan bisnis. Aspek sosial yang dimaksud dari hasil merger adalah berbagi hasil dengan masyarakat yang membutuhkan, baik dalam bentuk zakat, infaq, dan sedekah. Dalam pandangan Islam, merger dikenal sebagai Syirkah atau kerjasama. Sedangkan kerjasama merupakan hal yang sangat dianjurkan dalam Islam, sebagaimana firman Allah:

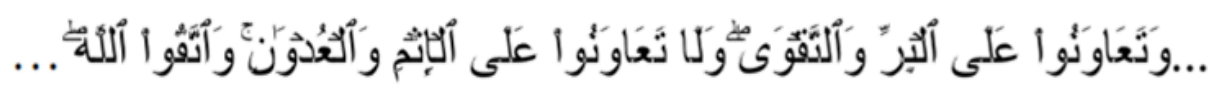

“...dan tolong-menolonglah kamu dalam (mengerjakan) kebajikan dan takwa, dan jangan tolong-menolong dalam berbuat dosa dan pelanggaran. Dan bertakwalah kamu kepada Allah...".

Berdasarkan ayat diatas, maka jelaslah bahwa kerjasama ini sangat penting bagi kehidupan manusia, yang dapat menimbulkan rasa setia kawan, sehingga mereka saling membantu dan bertolong menolong mencari rezeki yang halal serta mewujudkan kesejahteraan hidup mereka. Sedang tolong menolong dalam kebaikan dan ketaqwaan adalah suatu keharusan yang utama dalam agama islam. 
Merger sebagai bentuk kerjasama yang dilakukan oleh beberapa perusahaan sampel selanjutnya akan diumumkan kepada publik berkaitan dengan menjalin akad yang terbuka, jelas maksudnya, serta diterima oleh semua pihak guna memberikan informasi terhadap merger yang dilakukan perusahaan dan akan menciptakan keadilan, keharmonisan, dan keberkahan dalam usahanya. Sekaligus diharapkan mendatangkan kemaslahatan bersama baik itu masyarakat atau negara.

\section{KESIMPULAN}

Hasil pengujian dari kelima rasio, yaitu current ratio menunjukkan adanya perbedaan pada periode 2 tahun sebelum dan sesudah merger, sedangkan pada debt to equity ratio, net profit margin, return on equity dan return on assets menunjukkan bahwa tidak terdapat perbedaan sebelum dengan sesudah perusahaan melakukan merger pada periode penelitian. Hal ini dapat dimungkinkan untuk terjadi dikarenakan periode pengamatan dalam penelitian ini hanya empat tahun (dua tahun sebelum dengan dua tahun sesudah merger).

Merger yang dilakukan oleh perusahaan sampel yang terdaftar dalam Daftar Efek Syariah tidak bertentangan dengan hukum Islam, dengan prinsip kerjasama dan tolong menolong dalam upaya untuk tetap mempertahankan eksistensi perusahaan dan mencegah perusahaan sampel dari kebangkrutan dan adanya keterbukaan informasi serta jujur dalam penyampaian pengumuman merger.

\section{DAFTAR PUSTAKA}

Agung Wijaya, "Pengaruh Informasi Merger Terhadap Harga Saham Dan Volume Perdagangan Pada Perusahaan Yang Terdaftar Di Bursa Efek Indonesia", Universitas Ma Chung.

Annisa Meta. Cw, “Analisis Manajemen Laba Dan Kinerja Keuangan Perusahaan Pengakuisisi Sebelum Dan Sesudah Merger Dan Akuisisi Yang Terdaftar Di Bursa Efek Indonesia Tahun 2008-2009”.

Anwar, M. Ahmad, Prinsip-Prinsip Metodologi Research, Sumbangsih, Yogyakarta, 1975.

Arikunto, Suharsimi, Prosedur Penelitian Suatu Pendekatan Pratik, Cet.Ke 14, Rineka Cipta, Jakarta, 2010. 
Assauri, Sofjan, Strategic Management: Sustainable Competitive Advantages Edisi Kedua, Cetakan Pertama, Rajawali Pers, Jakarta, 2013.

At-Thayyib, Al-Quran Transliterasi Perkata dan Terjemah Perkata, Cipta Bagus Segara, 2011

Brealey, Myers dan Marcus, Dasar Dasar Manajemen Keuangan Perusahaan, Edisi Kelima, Erlangga, Jakarta, 2006

Brigham dan Houston, Manajemen Keuangan, Edisi Kedelapan, Erlangga, Jakarta, 2001.

Didin Hafidhuddin dan Hendri Tanjung, Manajemen Syariah Dalam Praktik, Gema Insani Press, Jakarta, 2003.

Dwi Martani dkk, Akuntansi Keuangan Menengah Berbasis PSAK, Salemba Empat, Jakarta, 2012.

Etta Mamang, Metodologi Penelitian, CV Andi, Yogyakarta, 2010.

Fahmi, Irham, Analisis Kinerja Keuangan Panduan bagi Akademisi, Manajer dan Investor untuk Menilai dan Menganalisis Bisnis dari Aspek Keuangan, Alfabeta, Bandung, 2011.

Analisis Laporan Keuangan, Alfabeta, Bandung, 2012

Hasan, Iqbal, Analisis Data Penelitian dengan Statistik, Cet.Ke 3, PT Bumi Aksara, Jakarta, 2008.

Hitt, Ireland dan Hoskisson, Manajemen Strategis: Daya Saing dan Globalisasi; Konsep, Salemba Empat, Jakarta, 2001.

Indah Rahmawati, "Pengaruh Merger Dan Akuisisi Terhadap Kinerja Keuangan Perusahaan Manufaktur Go Public Di Indonesia (Studi Di Bursa Efek Jakarta), 2007”.

Ismariyah, Merger Bank Dalam Tinjauan Hukum Islam,Universitas Islam Negeri Sunan Kalijaga, 2007

Jumingan, Analisis Laporan Keuangan, Cetakan Pertama, Bumi Aksara, Jakarta, 2011.

Komunitas Ekononomi Syariah, Kamus Istilah Perbankan dan Asuransi Syariah, Shahih, Jakarta, 2016. 
Kurniawan, Tri Andi, Analisis Perbandingan Kinerja Keuangan Perusahaan Sebelum dan Sesudah Merger dan Akuisisi (Pada Perusahaan Manufaktur di BEI Tahun 2003-2007), Universitas Diponegoro, Semarang, 2011

Lenny Setiawaty dan Suzanna Lamria Siregar, "Analisis Rasio Keuangan Untuk Menunjukkan Pengaruh Merger Terhadap Kinerja Keuangan Perusahaan Studi Kasus: PT Indofood Sukses Makmur, 2006”

Lukas Setia Atmaja, Teori dan Praktik Manajemen Keuangan, Edisi Pertama, ANDI, Jogyakarta

Masyhuri, M. Zainuddin, Metodologi Penelitian Pendekatan Praktis dan Aplikatif, Cet.Ke 2, PT Refika Aditama, Bandung, 2009.

Moin, Abdul, Merger Akuisisi \& Divestasi, Edisi Kedua, Ekonisia, Yogyakarta 2010.

M. Nazir, Metodologi penelitian, Ghalia Indonesia, Bogor, 2005.

Muhammad Nuh dan Suhajar Wiyoto, Accounting Principles, Lentera Ilmu, Jakarta Pusat, 2011.

Najmudin, Manajemen Keuangan dan Aktualisasi Syariah Modern, C.V Andi Offset, Yogyakarta, 2011.

Otoritas Jasa Keuangan, "Keputusan Dewan Komisioner OJK Nomor: KEP63/D.04/2015 tentang Daftar Efek Syariah"

Poerwadarminta, Kamus Umum Bahasa Indonesia, Balai Pustaka, Jakarta

Putri Novaliza dan Atik Djajanti, “Analisis Pengaruh Merger Dan Akuisisi Terhadap Kinerja Perusahaan Publik Di Indonesia (Periode 2004 - 2011) Jurnal Akuntansi dan Bisnis, Vol. 1 No. 1 September 2013.

Sugiyono, Metode Penelitian Bisnis, Cetakan ke-16, Alfabeta, Bandung, 2012 ------, Metode Penelitian Kuantitatif Kualitatif dan R\&D, Cetakan Ke-17, Alfabeta, Bandung, 2012.

Suhendi, Hendi, Fiqh Muamalah, Edisi 1 Cetakan ke-8, Rajawali Press, Jakarta, 2013.

Tika, Moh. Pabundu, Metodologi Risearch Bisnis, PT. Bumi Aksara, Jakarta, 2006. 
Zuliansyah, Ahmad, Manajemen Keuangan, Fakultas Syari'ah IAIN Raden Intan Lampung, Sukarame, 2014.

www.ksei.co.id 